\title{
Effects of myocardial viability and left ventricular remodeling on survival of patients with heart failure and reduced ejection fraction after coronary artery bypass grafting
}

\author{
Jian Cao ${ }^{1}$, Ran Dong', Kui Zhang', Hongjia Zhang ${ }^{1,2,3}$ \\ ${ }^{1}$ Department of Cardiac Surgery, Beijing Institute of Heart, Lung and Blood Vessel Diseases, Beijing Anzhen Hospital, Capital Medical University, \\ Beijing 100029, China; ${ }^{2}$ Beijing Lab for Cardiovascular Precision Medicine, Beijing 100029, China; ${ }^{3}$ Beijing Engineering Research Center for \\ Vascular Prostheses, Beijing 100029, China \\ Contributions: (I) Conception and design: H Zhang, R Dong, J Cao; (II) Administrative support: H Zhang, R Dong; (III) Provision of study materials \\ or patients: J Cao, R Dong; (IV) Collection and assembly of data: K Zhang, J Cao; (V) Data analysis and interpretation: K Zhang, J Cao; (VI) \\ Manuscript writing: All authors; (VII) Final approval of manuscript: All authors. \\ Correspondence to: Hongjia Zhang, MD. Department of Cardiac Surgery, Beijing Institute of Heart, Lung and Blood Vessel Diseases, Beijing Anzhen \\ Hospital, Capital Medical University, Beijing 100029, China. Email: zhanghongjia722@ccmu.edu.cn.
}

Background: Heart failure with reduced ejection fraction (HFrEF) caused by coronary heart disease (CHD) accounts for the largest proportion of patients with heart failure and is associated with the poorest prognosis. However, date on the perioperative risk and long-term survival of patients with HFrEF are limited. The present study aimed at exploring the effects of the left ventricular end-systolic volume index (LVESVI) and myocardial viability on perioperative risk and long-term survival after coronary artery bypass grafting (CABG) in patients with HFrEF.

Methods: This is a single center, prospective, observational study. CHD patients with symptoms and signs of heart failure and a left ventricular ejection fraction (LVEF) $<40 \%$ were enrolled consecutively from January 2014 to February 2018. Operative mortality, perioperative complications and long-term survival were compared in the patients with various LVESVIs and myocardial viabilities. The primary outcomes were cardiac death, myocardial infarction, heart failure, stroke and revascularization [percutaneous coronary intervention (PCI) or redo CABG] with a median follow-up of $30 \pm 12$ months.

Results: Perioperative mortality was $6.8 \%$ in the 118 patients in this study. Perioperative mortality was significantly higher in the low myocardial viability (LMV) group than in the high myocardial viability (HMV) group (12.5\% vs. 3.8\%, $\mathrm{P}=0.034)$. The 12-, 24-, 36-month major adverse cardiac event (MACE)-free survival rate of patients with HMV was significantly higher than that of patients with LMV (HMV vs. LMV: 96.9\% vs. $88.6 \%, 93.4 \%$ vs. $85.5 \%, 79.4 \%$ vs. $68.2 \%, \mathrm{P}=0.004)$. There was no difference in MACE-free survival among patients with different degrees of left ventricular remodeling within each group.

Conclusions: Myocardial viability is an important factor that affects the perioperative mortality and long-term survival of patients with ischemic HFrEF after CABG. Left ventricular remodeling increases perioperative mortality but has no effect on long-term survival.

Keywords: Coronary artery bypass grafting (CABG); heart failure with reduced ejection fraction (HFrEF); left ventricular remodeling; myocardial viability

Submitted Nov 29, 2019. Accepted for publication Jan 07, 2020.

doi: $10.21037 / \mathrm{cdt} .2020 .01 .11$

View this article at: http://dx.doi.org/10.21037/cdt.2020.01.11 


\section{Introduction}

Heart failure (HF) is a major public health problem in the world. The incidence of HF in developed countries is approximately $1-2 \%$ (1). Based on different ejection fractions (EFs), HF is divided into $\mathrm{HF}$ with reduced $\mathrm{EF}$ (HFrEF) and HF with preserved EF (HFpEF). According to statistics, HF is diagnosed in 5.1 million adults in the United States (2), at least $50 \%$ of whom are diagnosed with HFrEF [left ventricular (LV) EF <40\%] (3). The most common cause of HFrEF is ischemic heart disease, which accounts for approximately $60 \%$ of all cases (3). Compared with patients without HF, coronary heart disease (CHD) patients with HF have more clinical complications and higher incidences of bleeding and recurrent myocardial infarction; additionally, the treatments are inadequate, and the mortality is high (4). The prognosis of CHD patients with HFrEF is also significantly worse than that of nonCHD patients with HFrEF $(5,6)$. Therefore, how to effectively treat these patients is a topic worthy of exploring.

Many retrospective studies have shown that viable myocardium in the $\mathrm{LV}$ is an important predictor of whether patients with ischemic HF can benefit from coronary artery bypass grafting (CABG). On the other hand, the subgroup analysis in the surgical treatment for ischemic heart failure (STICH) trial suggested that viable myocardium had nothing to do with surgical benefits. In addition, many researchers believed that except for viable myocardium, the severity of LV remodeling is also an important indicator for assessing the efficacy of CABG. Therefore, the role of myocardial viability and $\mathrm{LV}$ remodeling and the interactions between them in CABG are not clear.

This study analyzed perioperative mortality, complications, and prognosis after CABG in patients with different $\mathrm{LV}$ size and myocardial viability, which aimed to explore the role of $\mathrm{LV}$ remodeling and myocardial viability and elucidate the clinical features of patients with HFrEF after CABG.

\section{Methods}

\section{Patient enrollment}

CHD patients with symptoms and signs of HF and an LVEF $<40 \%$ (determined by transthoracic ultrasonography) who were admitted to Ward 11 of the Department of Cardiac Surgery, Beijing Anzhen Hospital, from January 2014 to February 2018 were enrolled consecutively in this study. All patients had signed informed consent after admission. The exclusion criteria were patients with cardiogenic shock; patients with acute myocardial infarction within 3 months; and patients who need concurrent aortic valve surgery. According to the viable myocardium ratio, the patients were divided into two groups: (I) high myocardial viability (HMV): a ratio of viable to total myocardium in the $\mathrm{LV}$ $\geq 10 \%$; and (II) low myocardial viability (LMV): a ratio of viable to total myocardium in the $\mathrm{LV}<10 \%$. In addition, the patients were further divided into four subgroups according to the mean LV end-systolic volume index (LVESVI): (I) HMV with small LV (LVESVI $<92 \mathrm{~mL} / \mathrm{m}^{2}$ ), (II) HMV with large $L V$ (LVESVI $\geq 92 \mathrm{~mL} / \mathrm{m}^{2}$ ), (III) LMV with small LV (LVESVI $<92 \mathrm{~mL} / \mathrm{m}^{2}$ ), and (IV) LMV with large LV (LVESVI $\geq 92 \mathrm{~mL} / \mathrm{m}^{2}$ ). All patients used the following agents for more than a year: nitrates, aspirin, betaloc, statins and angiotensin-converting enzyme inhibitors (ACEIs) or angiotensin II receptor blockers (ARBs).

\section{Determination of viable myocardium}

All 118 enrolled patients underwent myocardial perfusion imaging at rest and myocardial metabolism tomography via positron emission tomography (PET) at the Department of Nuclear Medicine of Beijing Anzhen Hospital. The infarcted myocardium region was defined as the region in which the perfusion images were compatible with the metabolic data, while the viable myocardium region was defined as the region in which the perfusion images were not compatible with the metabolic data. The ratio of viable myocardium was calculated based on the number of viable segments. Based on the previous research $(7,8)$, a ratio of viable to total myocardium in the $\mathrm{LV}<10 \%$ was defined as $\mathrm{LMV}$, and a ratio $\geq 10 \%$ was defined as HMV.

\section{Determination of LVEF and LVESV}

Two sonographers performed transthoracic echocardiography to determine the LVEF and LVESV before surgery. Patients with an EF $<40 \%$ that was confirmed by the two sonographers were enrolled. If there was disagreement between the two sonographers regarding an EF, a third sonographer repeated the examination and confirmed the results. LVESV was the average of the two measurements. The LVESVI was obtained by normalizing the LVESV to the body surface area of the patient.

\section{Follow-up}

Follow-up was performed at 3, 6 and 12 months after 
surgery and then once a year. The clinical endpoints were obtained by telephone follow-up, door-to-door followup or clinical follow-up. The main examinations included echocardiography, electrocardiography, coronary computed tomography angiography (CTA), PET myocardial perfusion imaging at rest, PET myocardial metabolic tomography, routine blood tests, liver and kidney function tests and cardiac function tests. The primary endpoints were all-cause death and major adverse cardiac events (MACEs) which including revascularization, myocardial infarction, stroke, HF, death from cardiovascular cause.

\section{Statistical analysis}

This is a single center, prospective, observational study. SPSS 25.0 software was used for statistical analyses. The baseline characteristics of the groups were compared using Student's $t$-test for continuous variables and the $\chi^{2}$ statistic for categorical variables. Continuous variables were reported as mean with standard deviation and categorical variables were reported as percentage. Survival analysis was analyzed using Kaplan-Meier method. $\mathrm{P}<0.05$ was considered statistically significant.

\section{Results}

All 118 patients underwent myocardial perfusion imaging at rest and myocardial metabolism tomography via PET. The mean LVESVI was $92 \mathrm{~mL} / \mathrm{m}^{2}$. A total of 78 patients with a ratio of viable to total myocardium in the $\mathrm{LV} \geq 10 \%$ were included in the HMV group, and 40 patients with a ratio $<10 \%$ were included in the LMV group. There were no significant differences in preoperative LVEF, LVESVI, and cardiac function between the high and LMV groups. In the HMV group, the proportion of patients with previous interventional therapy was higher than that in the LMV group, which may be the reason why more viable myocardium was preserved in these patients (Table 1). In patients with HMV, the severity of LV remodeling was not correlated with patient EF and cardiac function (Table 2). In contrast, in patients with $\mathrm{LMV}$, the lower the EF and the worse the cardiac function were, the more severe the $\mathrm{LV}$ remodeling. In addition, in the LMV group, patients with severe $L V$ remodeling had a higher rate of previous myocardial infarction than did patients with mild LV remodeling (Table 3).

Perioperative mortality was $6.8 \%$ for the 118 patients.
Perioperative mortality was significantly higher in the LMV group than in the HMV group $(12.5 \%$ vs. $3.8 \%$, $\mathrm{P}=0.034)$, and the proportion of patients with mechanical assistance, such as extracorporeal membrane oxygenation (ECMO) and intra-aortic balloon pump (IABP), was higher in the former group than in the latter group during the perioperative period (IABP: $75.0 \%$ vs. $47.4 \%, \mathrm{P}=0.004$; ECMO: $22.5 \%$ vs. $1.3 \%, \mathrm{P}<0.010)$. Patients with LMV were more susceptible to atrial fibrillation (AF) after surgery than were with those with HMV $35.0 \%$ vs. $14.1 \%, \mathrm{P}=0.011$ ) (Table 4). Subgroup analysis was further performed according to a mean LVESVI of $92 \mathrm{~mL} / \mathrm{m}^{2}$. In the HMV group, the incidence of postoperative $\mathrm{AF}$ and the rate of IABP use were significantly higher in the patients with severe $\mathrm{LV}$ remodeling than in those with mild $\mathrm{LV}$ remodeling (AF: $25.0 \%$ vs. $6.5 \%, \mathrm{P}=0.024$; IABP: $62.5 \%$ vs. $36.9 \%, \mathrm{P}=0.031)$. The mortality was higher in the former group but not significantly different between the groups (6.3\% vs. $2.2 \%, \mathrm{P}=0.561$ ) (Table 5). In the LMV group, the rate of $\mathrm{ECMO}$ use and the incidence of postoperative $\mathrm{AF}$ in patients with severe $\mathrm{LV}$ remodeling were higher than those in patients with mild $\mathrm{LV}$ remodeling (ECMO use: $38.9 \%$ vs. 9.1\%, $\mathrm{P}=0.043$; AF incidence: $61.1 \%$ vs. $13.6 \%, \mathrm{P}=0.031$ ). Perioperative mortality reached $22.2 \%$ in the LMV group (Table 6). Thus, patients with LMV had the highest risk of surgery.

Follow-up was performed for 75 patients in the HMV group and 35 patients in the LMV group with a mean

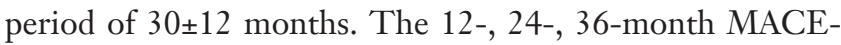
free survival rate of patients with HMV was significantly higher than that of patients with LMV (HMV vs. LMV: $96.9 \%$ vs. $88.6 \%, 93.4 \%$ vs. $85.5 \%, 79.4 \%$ vs. $68.2 \%$, $\mathrm{P}=0.004$, Figure $1 A$ ). There was no difference in MACEfree survival between patients with different degrees of $\mathrm{LV}$ remodeling within each group (Figure 1B,C). Patients with a high ratio of viable myocardium had a better prognosis, and the severity of $L V$ remodeling did not affect the long-term prognosis of patients. The details of MACEs are shown in Tables 7,8.

\section{Discussion}

The LVESVI is an important parameter for evaluating the severity of $\mathrm{LV}$ remodeling. The ratio of viable to total myocardium in the LV can accurately reflect the degree of myocardial infarction. Based on the LVESVI and myocardial viability, this study analyzed the perioperative 
Table 1 Baseline characteristics of patients in the high and low myocardial viability groups

\begin{tabular}{|c|c|c|c|}
\hline Variables & $\begin{array}{c}\text { Ratio of viable } \\
\text { myocardium } \geq 10 \% \\
(\mathrm{~N}=78)\end{array}$ & $\begin{array}{l}\text { Ratio of viable } \\
\text { myocardium } \\
<10 \%(\mathrm{~N}=40)\end{array}$ & $P$ value \\
\hline $\begin{array}{l}\text { Age, mean } \pm \text { SD } \\
\text { (years) }\end{array}$ & $59 \pm 8$ & $57 \pm 9$ & 0.961 \\
\hline Diabetes, n (\%) & $32(41.0)$ & $15(37.5)$ & 0.144 \\
\hline Hypertension, n (\%) & $41(52.6)$ & $22(55.0)$ & 0.062 \\
\hline $\begin{array}{l}\text { Hyperlipidemia, n } \\
(\%)\end{array}$ & 26 (33.3) & $10(25.0)$ & 0.872 \\
\hline CKD, n (\%) & $3(3.8)$ & $3(7.5)$ & 0.178 \\
\hline PVD, n (\%) & 9 (11.5) & $6(15.0)$ & 1.000 \\
\hline Prior CABG & 0 & 0 & NS \\
\hline Prior PCI, n (\%) & $21(26.9)$ & $10(25.5)$ & 0.053 \\
\hline Prior MI, n (\%) & $61(78.2)$ & $26(51.3)$ & 0.135 \\
\hline AF, n (\%) & $3(3.8)$ & $2(5.0)$ & 0.070 \\
\hline Prior stroke, n (\%) & $1(1.3)$ & 0 & NS \\
\hline NCAs, mean \pm SD & $2.9 \pm 0.6$ & $3.0 \pm 0.8$ & 0.331 \\
\hline LM disease, n (\%) & $9(11.5)$ & $5(12.5)$ & 0.776 \\
\hline NYHA, n (\%) & & & 0.231 \\
\hline I & $5(6.4)$ & $2(5.0)$ & \\
\hline II & 27 (34.6) & 7 (17.5) & \\
\hline III & $35(44.9)$ & $22(55.0)$ & \\
\hline IV & $11(14.1)$ & $6(15.0)$ & \\
\hline $\begin{array}{l}\text { BMI, mean } \pm \text { SD } \\
\left(\mathrm{kg} / \mathrm{m}^{2}\right)\end{array}$ & $25.1 \pm 2.8$ & $24.2 \pm 2.5$ & 0.633 \\
\hline $\begin{array}{l}\text { LVEF, mean } \pm \text { SD } \\
(\%)\end{array}$ & $33.5 \pm 3.8$ & $34.2 \pm 3.5$ & 0.835 \\
\hline LVEDVI $\left(\mathrm{mL} / \mathrm{m}^{2}\right)$ & $114 \pm 31$ & $118 \pm 35$ & 0.612 \\
\hline LVESVI $\left(\mathrm{mL} / \mathrm{m}^{2}\right)$ & $91 \pm 29$ & $94 \pm 36$ & 0.153 \\
\hline $\begin{array}{l}\text { Syntax score, mean } \\
\pm \text { SD }\end{array}$ & $43.3 \pm 3.7$ & $46.2 \pm 4.4$ & 0.771 \\
\hline
\end{tabular}

SD, standard deviation; CKD, chronic kidney disease; PVD, peripheral vascular disease; CABG, coronary artery bypass grafting; $\mathrm{PCl}$, percutaneous coronary intervention; $\mathrm{MI}$, myocardial infarction; AF, atrial fibrillation; NCAs, number of diseased coronary arteries; LM, left main disease; NYHA, New York Heart Association; BMI, body mass index; LVEF, left ventricle eject fraction; LVEDVI, left ventricle end-diastolic volume index; NS, no significance.
Table 2 Baseline characteristics of the subgroup of patients with high myocardial viability

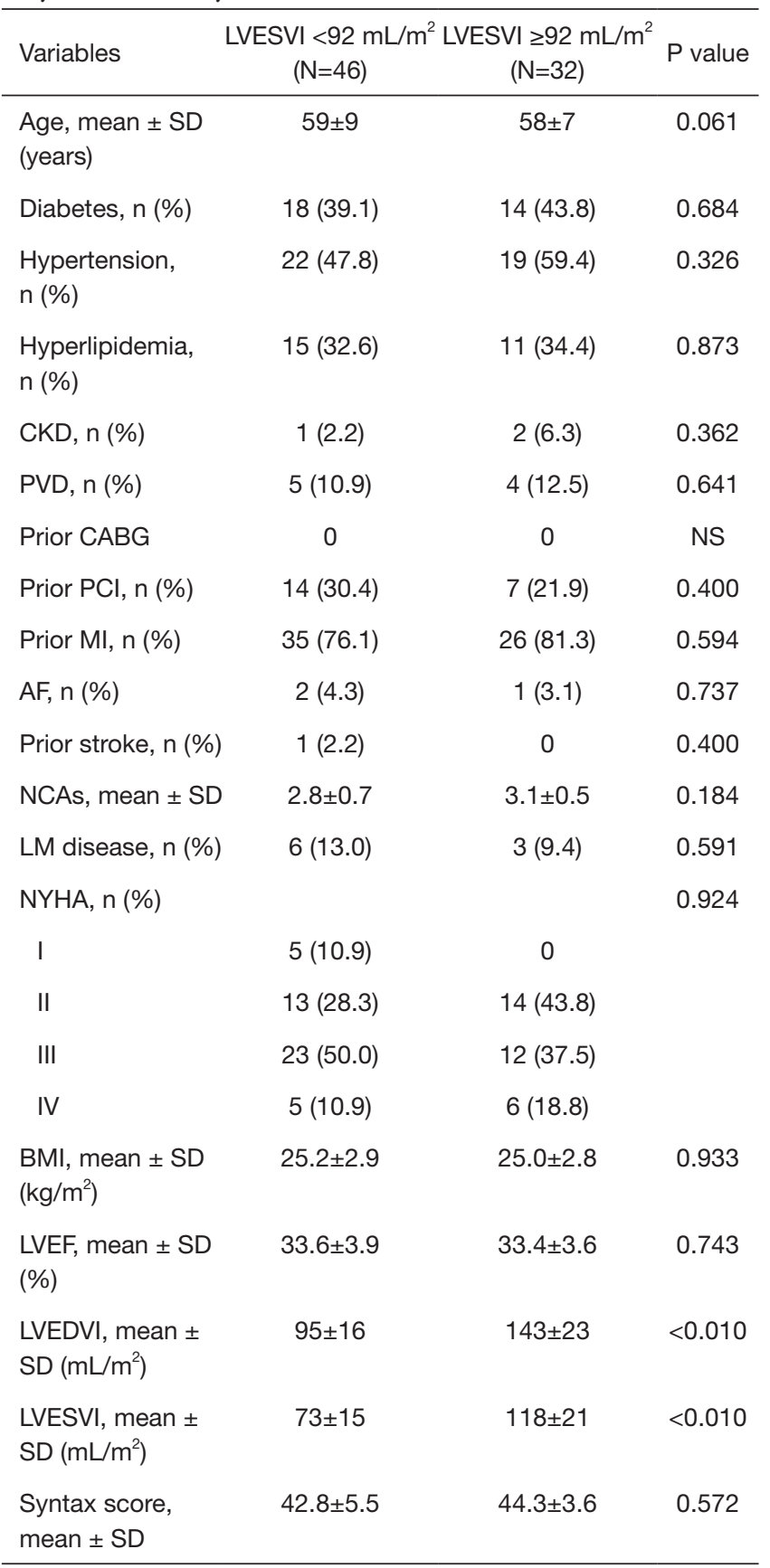

LVEDVI, left ventricle end-diastolic volume index; SD, standard deviation; CKD, chronic kidney disease; PVD, peripheral vascular disease; CABG, coronary artery bypass grafting; $\mathrm{PCl}$, percutaneous coronary intervention; MI, myocardial infarction; AF, atrial fibrillation; NCAs, number of diseased coronary arteries; LM, left main disease; NYHA, New York Heart Association; BMI, body mass index; LVEF, left ventricle eject fraction; NS, no significance. 
Table 3 Baseline characteristics of the subgroup of patients with low myocardial viability

\begin{tabular}{|c|c|c|c|}
\hline Variables & $\begin{array}{c}\text { LVESVI }<92 \mathrm{~mL} / \mathrm{m}^{2} \\
(\mathrm{~N}=22)\end{array}$ & $\begin{array}{c}\text { LVESVI } \geq 92 \mathrm{~mL} / \mathrm{m}^{2} \\
(\mathrm{~N}=18)\end{array}$ & $P$ value \\
\hline $\begin{array}{l}\text { Age, mean } \pm \\
\text { SD (years) }\end{array}$ & $56.5 \pm 9.1$ & $58.0 \pm 8.1$ & 0.596 \\
\hline Diabetes, n (\%) & $10(45.5)$ & $5(27.8)$ & 0.677 \\
\hline $\begin{array}{l}\text { Hypertension, } \\
\mathrm{n}(\%)\end{array}$ & $11(50.0)$ & $11(61.1)$ & 0.492 \\
\hline $\begin{array}{l}\text { Hyperlipidemia, } \\
\text { n (\%) }\end{array}$ & 6 (27.3) & $4(22.2)$ & 0.146 \\
\hline CKD, n (\%) & $2(9.1)$ & $1(5.6)$ & 0.181 \\
\hline PVD, n (\%) & $3(13.6)$ & $3(16.7)$ & 0.024 \\
\hline Prior CABG & 0 & 0 & NS \\
\hline Prior PCI, n (\%) & $6(27.3)$ & $4(22.2)$ & 0.147 \\
\hline Prior MI, n (\%) & $11(50.0)$ & 15 (83.3) & 0.021 \\
\hline AF, n (\%) & 0 & $2(11.1)$ & 0.086 \\
\hline Prior stroke & 0 & 0 & NS \\
\hline $\begin{array}{l}\text { NCAs, mean } \pm \\
\text { SD }\end{array}$ & $3.2 \pm 0.8$ & $2.8 \pm 0.7$ & 0.091 \\
\hline $\begin{array}{l}\text { LM disease, } n \\
(\%)\end{array}$ & $4(18.2)$ & $1(5.6)$ & 0.244 \\
\hline NYHA, n (\%) & & & 0.021 \\
\hline I & $2(9.1)$ & 0 & \\
\hline II & $6(27.3)$ & $1(5.6)$ & \\
\hline III & $10(45.5)$ & $12(66.7)$ & \\
\hline IV & $2(9.1)$ & $4(22.2)$ & \\
\hline $\begin{array}{l}\text { BMI, mean } \pm \\
\mathrm{SD}\left(\mathrm{kg} / \mathrm{m}^{2}\right)\end{array}$ & $24.7 \pm 2.4$ & $23.6 \pm 2.8$ & 0.172 \\
\hline $\begin{array}{l}\text { LVEF, mean } \pm \\
\text { SD }(\%)\end{array}$ & $35.5 \pm 3.3$ & $32.7 \pm 3.3$ & 0.012 \\
\hline $\begin{array}{l}\text { LVEDVI, mean } \\
\pm \mathrm{SD}\left(\mathrm{mL} / \mathrm{m}^{2}\right)\end{array}$ & $95 \pm 18$ & $147 \pm 30$ & $<0.010$ \\
\hline $\begin{array}{l}\text { LVESVI, mean } \\
\pm \mathrm{SD}\left(\mathrm{mL} / \mathrm{m}^{2}\right)\end{array}$ & $69 \pm 16$ & $125 \pm 28$ & $<0.010$ \\
\hline $\begin{array}{l}\text { Syntax score, } \\
\text { mean } \pm \text { SD }\end{array}$ & $43.8 \pm 2.8$ & $49.1 \pm 3.9$ & 0.444 \\
\hline
\end{tabular}

LVEDVI, left ventricle end-diastolic volume index; SD, standard deviation; CKD, chronic kidney disease; PVD, peripheral vascular disease; CABG, coronary artery bypass grafting; $\mathrm{PCl}$, percutaneous coronary intervention; $\mathrm{MI}$, myocardial infarction; AF, atrial fibrillation; NCAs, number of diseased coronary arteries; LM, left main disease; NYHA, New York Heart Association; BMI, body mass index; LVEF, left ventricle eject fraction; LVEDVI, left ventricle end-diastolic volume index; NS, no significance. risk and long-term survival of CHD patients with $\mathrm{HFrEF}$ who underwent CABG. This study suggests that patients with a ratio of viable myocardium $\geq 10 \%$ and mild $L V$ remodeling have an acceptable operative mortality of $2.2 \%$. However, patients with a ratio of viable myocardium $<10 \%$ and a significantly enlarged $\mathrm{LV}$ have a high perioperative risk, $22.2 \%$, indicating that surgical indications for these patients need to be fully evaluated. Myocardial viability is an important factor that affects the perioperative mortality and long-term survival of patients with ischemic HFrEF after CABG. The LVESVI is an indicator for perioperative mortality in patients with LMV but is not an indicator for long-term survival.

Beginning with the pioneers Isom and Baird $(9,10)$, cardiac surgeons have made sustained efforts to reduce the surgery mortality of CHD patients with $\mathrm{LV}$ dysfunction. In the 1970s and 1980s, the mortality rates were $15 \%$ and $10 \%$, respectively. Currently, the mortality rate is less than $5 \%$ for CHD patients with an EF between 10\% and 30\% who undergo CABG (10-16). For the patients enrolled in this study, the average LVEF was 33\% (23-39\%), and the overall mortality was $6.8 \%(8 / 118)$. The subgroup analysis showed that the operative mortality was $2.2 \%$ in patients with a ratio of viable myocardium $\geq 10 \%$ and low LVESVI. This result suggests that these patients are suitable for CABG. However, the operative mortality reached $22.2 \%$ in patients with a ratio of viable myocardium $<10 \%$ and high LVESVI. Determining whether these patients are suitable for CABG requires a joint evaluation with cardiologists to develop an individualized treatment plan. In this current study, there was no significant difference in the LVESVI between the HMV group and the LMV group $(91 \pm 29$ vs. $94 \pm 36, \mathrm{P}=0.153)$, but operative mortality, incidence of postoperative $\mathrm{AF}$ and percentage of perioperative mechanical assistance were lower in the former than in the latter $(3.8 \%$ vs. $12.5 \%, \mathrm{P}=0.034 ; 14.1 \%$ vs. $35.0 \%$ $\mathrm{P}=0.011$; IABP: $75.0 \%$ vs. $47.4 \% \mathrm{P}=0.004$; $\mathrm{ECMO}: 22.5 \%$ vs. $1.3 \%, \mathrm{P}<0.010)$. This suggests that myocardial viability is an important factor that affects operative mortality and complications and should be fully assessed before surgery. In addition, the LVESVI is positively associated with mortality in patients with similar myocardial viabilities and is another important factor that affects operative mortality and complications. Therefore, for CHD patients with HFrEF, a preoperative risk assessment should not only consider the viable myocardium ratio but also consider the severity of $L V$ remodeling.

In terms of long-term prognosis, a series of previous 
Table 4 Surgical data of patients in the high and low myocardial viability groups

\begin{tabular}{|c|c|c|c|}
\hline Variables & $\begin{array}{l}\text { Ratio of viable } \\
\text { myocardium } \\
\geq 10 \%(\mathrm{~N}=78)\end{array}$ & $\begin{array}{l}\text { Ratio of viable } \\
\text { myocardium } \\
<10 \%(\mathrm{~N}=40)\end{array}$ & $P$ value \\
\hline $\begin{array}{l}\text { Operative time, } \\
\text { mean } \pm S D(\min )\end{array}$ & $241 \pm 58$ & $256 \pm 66$ & 0.163 \\
\hline Off-pump, n (\%) & $61(78.2)$ & $23(57.5)$ & 0.032 \\
\hline $\begin{array}{l}\text { Number of grafts, } \\
\text { mean } \pm S D\end{array}$ & $3.3 \pm 0.8$ & $3.1 \pm 0.6$ & 0.252 \\
\hline Total SVGs, n (\%) & $32(41.0)$ & $15(37.5)$ & 0.715 \\
\hline MVP/MVR, n (\%) & $6(7.7)$ & $12(30.0)$ & 0.004 \\
\hline $\begin{array}{l}\text { RBC transfusion, } \\
\text { mean } \pm S D(U)\end{array}$ & $1.1 \pm 1.9$ & $1.8 \pm 1.7$ & 0.481 \\
\hline $\begin{array}{l}\text { Plasma transfusion, } \\
\text { mean } \pm S D(m L)\end{array}$ & $102 \pm 236$ & $130 \pm 184$ & 0.627 \\
\hline $\begin{array}{l}\text { ICU stay, mean } \pm \\
\text { SD }(h)\end{array}$ & $74 \pm 72$ & $94 \pm 49$ & 0.334 \\
\hline $\begin{array}{l}\text { Duration of MV, } \\
\text { mean } \pm S D(h)\end{array}$ & $51 \pm 53$ & $69 \pm 49$ & 0.071 \\
\hline \multicolumn{4}{|l|}{$\begin{array}{l}\text { Complications, } \mathrm{n} \\
(\%)\end{array}$} \\
\hline Death & $3(3.8)$ & $5(12.5)$ & 0.034 \\
\hline Cardiac arrest & $2(2.6)$ & $4(10.0)$ & 0.082 \\
\hline Stroke & 0 & 0 & NS \\
\hline PMI & $2(2.6)$ & $2(5.0)$ & 0.491 \\
\hline AF & $11(14.1)$ & $14(35.0)$ & 0.011 \\
\hline $\begin{array}{l}\text { Pulmonary } \\
\text { infection }\end{array}$ & $11(14.1)$ & $9(22.5)$ & 0.255 \\
\hline Tracheotomy, n (\%) & $1(1.3)$ & 0 & 0.473 \\
\hline CRRT, n (\%) & $5(6.4)$ & $6(15.0)$ & 0.133 \\
\hline $\begin{array}{l}\text { Secondary } \\
\text { thoracotomy, n (\%) }\end{array}$ & 0 & $2(5.0)$ & 0.116 \\
\hline IABP, n (\%) & $37(47.4)$ & $30(75.0)$ & 0.004 \\
\hline $\begin{array}{l}\text { IABP time, mean } \pm \\
\text { SD (h) }\end{array}$ & $115 \pm 89$ & $113 \pm 51$ & 0.092 \\
\hline ECMO, n (\%) & $1(1.3)$ & $9(22.5)$ & $<0.010$ \\
\hline
\end{tabular}

SD, standard deviation; SVG, saphenous vein graft; MVP/ MVR, mitral valve plasty/mitral valve replacement; RBC, red blood cell; ICU, intensive care unit; MV, mechanical ventilation; $\mathrm{PMI}$, postoperative myocardial infarction; $\mathrm{AF}$, atrial fibrillation; CRRT, continuous renal replace therapy; IABP, intra-aortic artery balloon pump; ECMO, extracorporeal membrane oxygenation; NS, no significance.
Table 5 Surgical data of patients in the high myocardial viability group

\begin{tabular}{|c|c|c|c|}
\hline Variables & $\begin{array}{c}\text { LVESVI }<92 \mathrm{~mL} \\
\qquad(\mathrm{~N}=46)\end{array}$ & $\begin{array}{l}\mathrm{SVI} \geq 92 \mathrm{~mL} / \mathrm{m}^{2} \\
\quad(\mathrm{~N}=32)\end{array}$ & $P$ value \\
\hline $\begin{array}{l}\text { Operative time, } \\
\text { mean } \pm S D(\min )\end{array}$ & $244 \pm 67$ & $236 \pm 43$ & 0.241 \\
\hline Off-pump, n (\%) & 36 (78.3) & $25(78.1)$ & 0.962 \\
\hline $\begin{array}{l}\text { Number of } \\
\text { grafts, mean } \pm \\
\text { SD }\end{array}$ & $3.3 \pm 0.8$ & $3.1 \pm 0.6$ & 0.334 \\
\hline $\begin{array}{l}\text { Total SVGs, n } \\
\text { (\%) }\end{array}$ & $18(39.1)$ & $14(43.8)$ & 0.686 \\
\hline MVP/MVR, n (\%) & $4(8.7)$ & $5(15.6)$ & 0.417 \\
\hline $\begin{array}{l}\text { RBC transfusion, } \\
\text { mean } \pm S D(U)\end{array}$ & $1.1 \pm 2.0$ & $1.0 \pm 1.7$ & 0.492 \\
\hline $\begin{array}{l}\text { Plasma } \\
\text { transfusion, } \\
\text { mean } \pm S D(m L)\end{array}$ & $73 \pm 224$ & $143 \pm 250$ & 0.193 \\
\hline $\begin{array}{l}\text { ICU stay, mean } \\
\pm S D(h)\end{array}$ & $73 \pm 82$ & $76 \pm 57$ & 0.533 \\
\hline $\begin{array}{l}\text { Duration of MV, } \\
\text { mean } \pm S D(h)\end{array}$ & $52 \pm 58$ & $51 \pm 44$ & 0.434 \\
\hline \multicolumn{4}{|l|}{$\begin{array}{l}\text { Complications, } \mathrm{n} \\
(\%)\end{array}$} \\
\hline Death & $1(2.2)$ & $2(6.3)$ & 0.561 \\
\hline Cardiac arrest & 0 & $2(6.3)$ & 0.512 \\
\hline Stroke & 0 & 0 & NS \\
\hline PMI & $1(2.2)$ & $1(3.1)$ & 0.794 \\
\hline AF & $3(6.5)$ & $8(25.0)$ & 0.024 \\
\hline $\begin{array}{l}\text { Pulmonary } \\
\text { infection }\end{array}$ & $6(13.0)$ & $5(15.6)$ & 0.751 \\
\hline Tracheotomy & 0 & $1(3.1)$ & 0.417 \\
\hline CRRT, n (\%) & $2(4.3)$ & $3(9.4)$ & 0.393 \\
\hline $\begin{array}{l}\text { Secondary } \\
\text { thoracotomy }\end{array}$ & 0 & 0 & NS \\
\hline IABP, n (\%) & $17(36.9)$ & $20(62.5)$ & 0.031 \\
\hline $\begin{array}{l}\text { IABP time, mean } \\
\pm \mathrm{SD}(\mathrm{h})\end{array}$ & $96 \pm 50$ & $130 \pm 108$ & 0.143 \\
\hline ECMO, n (\%) & $1(2.2)$ & 0 & 1.000 \\
\hline
\end{tabular}

LVEDVI, left ventricle end-diastolic volume index; SD, standard deviation; SVG, saphenous vein graft; MVP/MVR, mitral valve plasty/mitral valve replacement; RBC, red blood cell; ICU, intensive care unit; MV, mechanical ventilation; PMI, postoperative myocardial infarction; AF, atrial fibrillation; CRRT, continuous renal replace therapy; IABP, intra-aortic artery balloon pump; ECMO, extracorporeal membrane oxygenation; NS, no significance. 
Table 6 Surgical data of patients in the low myocardial viability group

\begin{tabular}{|c|c|c|c|}
\hline Variables & $\begin{array}{c}\text { LVESVI }<92 \mathrm{~mL} \\
(\mathrm{~N}=22)\end{array}$ & $\begin{array}{l}\mathrm{SVI} \geq 92 \mathrm{~mL} / \mathrm{m}^{2} \\
\quad(\mathrm{~N}=18)\end{array}$ & $P$ value \\
\hline $\begin{array}{l}\text { Operative time, } \\
\text { mean } \pm S D(\min )\end{array}$ & $279 \pm 74$ & $241 \pm 58$ & 0.144 \\
\hline Off-pump, n (\%) & $12(54.5)$ & $10(55.6)$ & 0.763 \\
\hline $\begin{array}{l}\text { Number of grafts, } \\
\text { mean } \pm S D\end{array}$ & $3.1 \pm 0.6$ & $3.2 \pm 0.8$ & 0.861 \\
\hline Total SVGs, n (\%) & $8(36.4)$ & 7 (38.9) & 0.872 \\
\hline MVP/MVR, n (\%) & $2(9.1)$ & $10(55.6)$ & $<0.010$ \\
\hline $\begin{array}{l}\text { RBC transfusion, } \\
\text { mean } \pm S D(U)\end{array}$ & $2.4 \pm 1.8$ & $1.1 \pm 1.6$ & 0.633 \\
\hline $\begin{array}{l}\text { Plasma } \\
\text { transfusion, } \\
\text { mean } \pm S D(m L)\end{array}$ & $118 \pm 147$ & $144 \pm 225$ & 0.661 \\
\hline $\begin{array}{l}\text { ICU stay, mean } \pm \\
\text { SD }(h)\end{array}$ & $97 \pm 40$ & $90 \pm 60$ & 0.982 \\
\hline $\begin{array}{l}\text { Duration of MV, } \\
\text { mean } \pm S D(h)\end{array}$ & $72 \pm 32$ & $66 \pm 25$ & 0.727 \\
\hline \multicolumn{4}{|l|}{$\begin{array}{l}\text { Complications, } \mathrm{n} \\
(\%)\end{array}$} \\
\hline Death & $1(4.5)$ & $4(22.2)$ & $<0.010$ \\
\hline Cardiac arrest & $2(9.1)$ & $2(11.1)$ & 1.000 \\
\hline Stroke & 0 & 0 & NS \\
\hline PMI & $2(9.1)$ & 0 & 0.493 \\
\hline AF & $3(13.6)$ & $11(61.1)$ & 0.031 \\
\hline $\begin{array}{l}\text { Pulmonary } \\
\text { infection }\end{array}$ & $5(22.7)$ & $4(22.2)$ & 0.972 \\
\hline Tracheotomy & 0 & 0 & NS \\
\hline CRRT, n (\%) & $3(13.6)$ & $3(16.7)$ & 0.794 \\
\hline $\begin{array}{l}\text { Secondary } \\
\text { thoracotomy, n } \\
(\%)\end{array}$ & $1(4.5)$ & $1(5.6)$ & 0.892 \\
\hline IABP, n (\%) & $18(81.8)$ & $12(66.7)$ & 0.277 \\
\hline $\begin{array}{l}\text { IABP time, mean } \\
\pm S D(h)\end{array}$ & $110 \pm 46$ & $118 \pm 62$ & 0.686 \\
\hline ECMO, n (\%) & $2(9.1)$ & 7 (38.9) & 0.043 \\
\hline
\end{tabular}

LVEDVI, left ventricle end-diastolic volume index; SD, standard deviation; SVG, saphenous vein graft; MVP/MVR, mitral valve plasty/mitral valve replacement; $\mathrm{RBC}$, red blood cell; $I C U$, intensive care unit; MV, mechanical ventilation; PMI, postoperative myocardial infarction; AF, atrial fibrillation; CRRT, continuous renal replace therapy; IABP, intra-aortic artery balloon pump; ECMO, extracorporeal membrane oxygenation; NS, no significance. studies suggested that improvement in cardiac function after $C A B G$ is common in patients with a certain myocardial viability and mild $\mathrm{LV}$ remodeling. In patients with severe LV remodeling, regardless of the degree of myocardial viability, postoperative cardiac function is not significantly improved. Yamaguchi et al. (17) observed 20 patients with an LVEF $<30 \%$ who underwent CABG and found that the patients with an LVESVI $<100 \mathrm{~mL} / \mathrm{m}^{2}$ had significantly improved postoperative cardiac function, while patients with an LVESVI $\geq 100 \mathrm{~mL} / \mathrm{m}^{2}$ did not have significant improvement compared to preoperative cardiac function. Similarly, Bax et al. (18) showed significant improvement in postoperative cardiac function in patients with a mean LVEF of $29 \%$, certain myocardial viability $\left\{\left[{ }^{18} \mathrm{~F}\right]\right.$-fluorodeoxyglucose $\left({ }^{18} \mathrm{FDG}\right)$ single photon emission computed tomography (SPECT)] and a small end-systolic volume (ESV). Schinkel et al. (19) used dobutamine stress echocardiography to measure myocardial viability. Their results were consistent with previous studies and showed the ESV was negatively correlated with LVEF. Mandegar et al. (20) performed CABG in 85 patients with an LVEF $<35 \%$. Preoperative myocardial viability was assessed by dobutamine stress echocardiography. The follow-up showed that patients with more than six viable myocardial segments had an improved postoperative EF, while patients with less than six viable myocardium segments and a high ESV had no improvement in postoperative EF. However, none of these studies analyzed the long-term survival of patients. Moreover, SPECT and dobutamine stress echocardiography are not the best methods for determining myocardial viability. In this study, myocardial viability of the patients was determined by PET, and the long-term event-free survival of patients was analyzed, addressing the shortcomings of the aforementioned studies. The mean follow-up period in this study was $30 \pm 12$ months. The event-free survival rate in the HMV group was significantly higher than that in the LMV group. There was no correlation between the LVESVI and event-free survival in patients with similar myocardial viabilities. That suggests that myocardial viability is an important factor that affects the long-term survival of patients. The severity of LV remodeling is not related to long-term survival. Considering this study and previous studies, there seems to be no correlation between $L V$ remodeling and postoperative LV function improvement or long-term survival. However, interactions between and among the three parameters need to be determined through further studies. 

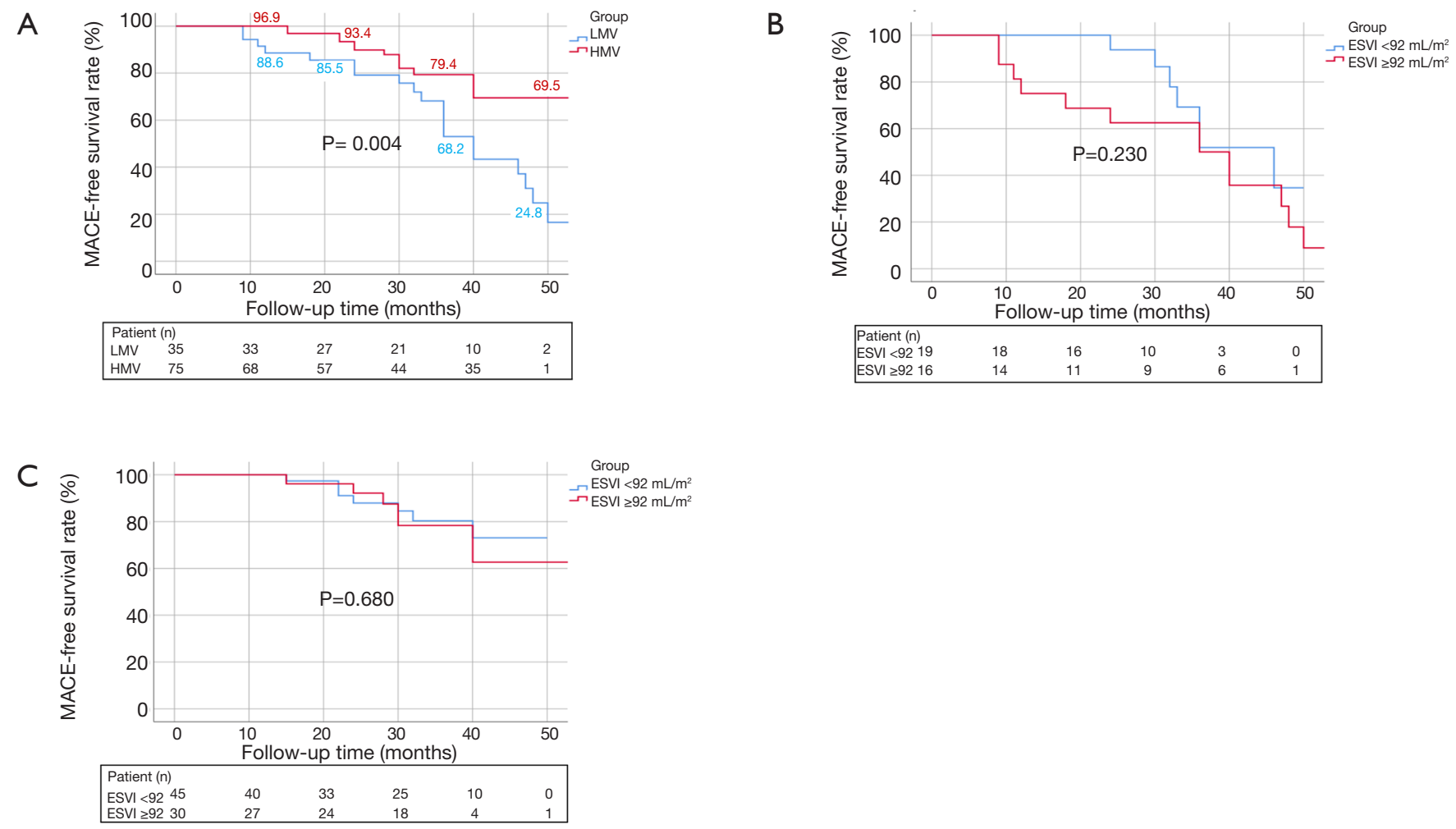

Figure 1 Kaplan-Meier analysis of MACE-free survival in patients with different myocardial viability and ventricle remodeling. (A) Survival of patients in the high and low myocardial viability groups. The 12-, 24-, 36-month MACE-free survival rate of patients with HMV was significantly higher than that of patients with LMV (HMV vs. LMV: 96.9\% vs. 88.6\%, 93.4\% vs. 85.5\%, 79.4\% vs. 68.2\%, P=0.004). (B) Survival of patients in the low myocardial viability group, there was no difference in MACE-free survival rate between patients with different degrees of left ventricular remodeling within each group. (C) Survival of patients in the high myocardial viability group, there was no difference in MACE-free survival rate between patients with different degrees of left ventricular remodeling within each group. LMV, low myocardial viability. HMV, high myocardial viability; MACE, major adverse cardiac event; ESVI, end-systolic volume index.

Table 7 Follow-up outcomes of patients in the high and low myocardial viability groups

\begin{tabular}{lccc}
\hline MACEs & $\operatorname{HMV}(\mathrm{n}=75), \mathrm{n}(\%)$ & $\mathrm{LMV}(\mathrm{n}=35), \mathrm{n}(\%)$ & $\mathrm{P}$ value \\
\hline Cardiac death & 0 & $1(2.9)$ & 0.154 \\
Stroke & $7(9.3)$ & $4(11.4)$ & 0.000 \\
MI & $13(17.3)$ & $7(20.0)$ & 0.005 \\
HF & $15(20.0)$ & $10(28.6)$ & 0.570 \\
Revascularization & $5(6.7)$ & $3(8.6)$ & 0.000
\end{tabular}

MACEs, major adverse cardiac events; MI, myocardium infarction; HMV, high myocardial viability; LMV, low myocardial viability; MI, myocardium infarction; HF, heart failure.

\section{Limitation of the study}

Due to the small sample size in this study, we used $10 \%$ as the viable myocardium ratio cut-off value to divide the patients into the low viability and high viability groups; however, two groups were not adequate. When more patients are enrolled in the study, another group, viable myocardium ratio between $10 \%$ to $20 \%$ will be added. This will further help in understanding the effects of the viable myocardium ratio on perioperative risk and long-term prognosis. Similarly, due to the small sample size in this study, the LVESVI cut-off value was the mean LVESVI, $92 \mathrm{~mL} / \mathrm{m}^{2}$. We concluded that $\mathrm{LV}$ remodeling does not affect the survival of patients. However, this conclusion may not be accurate. As the sample size increases, we will 
Table 8 Follow-up outcomes of patients with different LVESVI

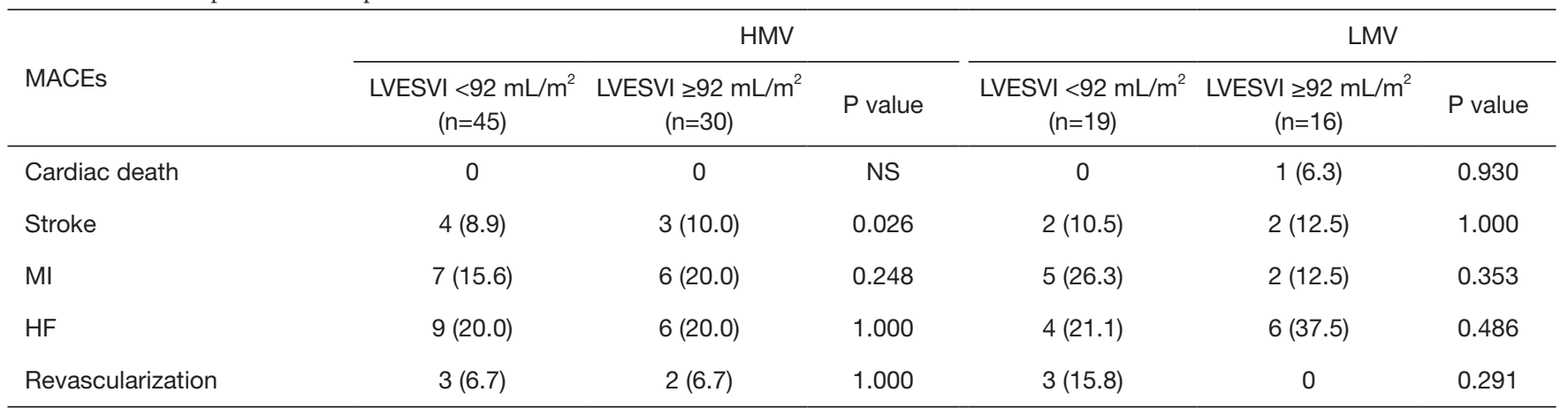

LVESVI, left ventricle end-systolic volume index; MACEs, major adverse cardiac events; MI, myocardium infarction; HMV, high myocardial viability; LMV, low myocardial viability; MI, myocardium infarction; HF, heart failure.

further scientifically classify the severity of $L V$ remodeling $\left(<60 \mathrm{~mL} / \mathrm{m}^{2}, 60-90 \mathrm{~mL} / \mathrm{m}^{2},>90 \mathrm{~mL} / \mathrm{m}^{2}\right)$ to more rationally evaluate the impact of $\mathrm{LV}$ remodeling on perioperative risk and long-term survival.

\section{Conclusions}

The results of this study suggest that patients with a low viable myocardium ratio and significant $L V$ enlargement have a high perioperative risk and that patients with a low viable myocardium ratio have a poor prognosis. Myocardial viability is an important factor that affects the perioperative mortality and long-term survival of post-CABG patients with ischemic HFrEF. LV remodeling increases perioperative mortality but has no effect on long-term survival.

\section{Acknowledgments}

Funding: This work was supported by the grant from Beijing Lab for Cardiovascular Precision Medicine, Beijing, China (2016-2020, Code: PXM2019_014226_000023), National Key R\&D Program of China (Code: 2017YFC1308000) and Beijing Municipal Administration of Hospitals' Ascent Plan (Code: DFL20180602).

\section{Footnote}

Conflicts of Interest: All authors have completed the ICMJE uniform disclosure form (available at http://dx.doi. org/10.21037/cdt.2020.01.11). The authors have no conflicts of interest to report.

Ethical Statement: The authors are accountable for all aspects of the work in ensuring that questions related to the accuracy or integrity of any part of the work are appropriately investigated and resolved. The study was approved by the Institutional Ethics Committee of Beijing Anzhen Hospital (No. 2016024).

Open Access Statement: This is an Open Access article distributed in accordance with the Creative Commons Attribution-NonCommercial-NoDerivs 4.0 International License (CC BY-NC-ND 4.0), which permits the noncommercial replication and distribution of the article with the strict proviso that no changes or edits are made and the original work is properly cited (including links to both the formal publication through the relevant DOI and the license). See: https://creativecommons.org/licenses/by-nc-nd/4.0/.

\section{References}

1. Go AS, Mozaffarian D, Roger VL, et al. Heart disease and stroke statistics--2014 update: a report from the American Heart Association. Circulation 2014;129:e28-292.

2. Owan TE, Hodge DO, Herges RM, et al. Trends in prevalence and outcome of heart failure with preserved ejection fraction. N Engl J Med 2006;355:251-9.

3. Yancy CW, Jessup M, Bozkurt B, et al. for the American College of Cardiology Foundation; American Heart Association Task Force on Practice Guidelines. 2013 ACCF/AHA Guideline for the management of heart failure: a report of the American College of Cardiology Foundation/American Heart Association Task Force on Practice Guidelines. J Am Coll Cardiol 2013;62:e147-239.

4. Felker GM, Shaw LK, O'Connor CM. A standardized definition of ischemic cardiomyopathy for use in clinical 
research. J Am Coll Cardiol 2002;39:210-8.

5. McMurray JJ, Adamopoulos S, Anker SD, et al. ESC guidelines for the diagnosis and treatment of acute and chronic heart failure 2012: the TaskForce for the Diagnosis and Treatment of Acute and Chronic Heart Failure 2012 of the European Society of Cardiology. Developed in collaboration with the Heart Failure Association (HFA) of the ESC. Eur Heart J 2012;33:1787-847.

6. Manley JC, King JF, Zeft HJ, et al. The "bad" left ventricle: results of coronary surgery and effect on late survival. J Thorac Cardiovasc Surg 1976;72:841-8.

7. Beanlands RS, Nichol G, Huszti E, et al. F-18fluorodeoxyglucose positron emission tomography imaging-assisted management of patients with severe left ventricular dysfunction and suspected coronary disease: a randomized, controlled trial (PARR-2). J Am Coll Cardiol 2007;50:2002-12.

8. Keiichiro Yoshinaga, Benjamin J.W. Chow, Kathryn Williams, et al. What is the Prognostic Value of Myocardial Perfusion Imaging Using Rubidium-82 Positron Emission Tomography? JACC 2006;48:1029-39.

9. Isom OW, Spencer FC, Glassman E, et al. Long-term survival following coronary bypass surgery in patients with significant impairment of left ventricular function. Circulation 1975;52:I141-7.

10. Hung J, Kelly DT, Baird DK, et al. Aorta coronary bypass grafting in patients with severe left ventricular dysfunction. J Thorac Cardiovasc Surg 1980;79:718-23.

11. Mickleborough LL, Carson S, Tamariz M, et al. Results of revascularisation in patients with severe left ventricular dysfunction. J Thorac Cardiovasc Surg 2000;119:550-7.

12. Chan RKM, Raman J, Lee KJ, et al. Prediction of outcome after revascularisation in patients with poor left ventricular function. Ann Thorac Surg 1996;61:1428-34.

13. Cimochowski GE, Harostock MD, Foldes PJ. Minimal

Cite this article as: Cao J, Dong R, Zhang K, Zhang $\mathrm{H}$. Effects of myocardial viability and left ventricular remodeling on survival of patients with heart failure and reduced ejection fraction after coronary artery bypass grafting. Cardiovasc Diagn Ther 2020;10(2):183-192. doi: 10.21037/cdt.2020.01.11 operative mortality in patients undergoing coronary artery bypass with significant left ventricular dysfunction by maximization of metabolic and mechanical support. J Thorac Cardiovasc Surg 1997;113:655-64; discussion 664-6.

14. Luciani GB, Montalbano G, Casali G, et al. Predicting long-term functional results after myocardial revascularization in alchemic cardiomyopathy. J Thorac Cardiovasc Surg 2000;120:478-89.

15. Antunes PE, Ferrao de Oliveira JM, Antunes MJ. Coronary surgery with noncardioplegic methods in patients with advanced left ventricular dysfunction: immediate and longterm results. Heart 2003;89:427-31.

16. Shapira I, Isakov A, Yakirevich V, et al. Long- term results of coronary artery bypass surgery in patients with severely depressed left ventricular function. Chest 1995;108:1546-50.

17. Yamaguchi A, Ino $\mathrm{T}$, Adachi $\mathrm{H}$, et al. Left ventricular end-systolic volume index in patients with ischemic cardiomyopathy predicts postoperative ventricular function. Ann Thorac Surg 1995;60:1059-62.

18. Bax JJ, Schinkel AF, Boersma E, et al. Extensive left ventricular remodeling does not allow viable myocardium to improve in left ventricular ejection fraction after revascularization and is associated with worse long-term prognosis. Circulation 2004;110:II18-22.

19. Schinkel AFL, Poldermans D, Rizzello V, et al. Why do patients with ischemic cardiomyopathy and a substantial amount of viable myocardium not always recover in function after revascularization? J Thorac Cardiovasc Surg 2004;127:385-90.

20. Mandegar MH, Yousefnia MA, Roshanali F, et al. Interaction between two predictors of functional outcome after revascularization in ischemic cardiomyopathy: left ventricular volume and amount of viable myocardium. J Thorac Cardiovasc Surg 2008;136:930-6. 